\title{
数学船型の規則波中に扔ける船体運動之抵抗増加
}

\author{
正員 中 村 彰 一* \\ 正員新谷厚**
}

On Ship Motions and Resistance Increase of Mathematical Ship Forms in Regular Waves

By Shoichi Nakamura, Member

Atsushi Shintani, Member

Summary

Amplitudes and phases of pitching and heaving of three models having simple mathematical ship forms in regular head waves are calculated by the strip method. The solutions to the coupled and uncoupled motions are obtained, and their results are compared.

Resistance increases of the models in regular head waves with three different wave lengths are also calculated by Maruo's approximate method. A modified method taking into account the effect of forward speed on the vertical velocity of ship sections are also examined.

The motions of the same models as well as the resistance increase in waves are measured and the results are compared with these calculations.

\section{1 緒䓂}

波浪中に括ける船体運動や抵抗増加等の耐航性能に関する研究の発展は最近著しいものがある。規則波中に捛 奵る上下摇, 緃摇の計算は実用船型に対して strip methodにより実験值とかなりよい一致を示す結果が得られ ることが判明している。しかしながらこの計算法自体にかなりの仮定が含まれているため, 現在の段階でこれを 全面的に信頼することにはいささか疑問が感じられる。一方波浪中抵抗増加に関しては, 丸尾によつてそれが本 質的に造波抵抗の増加であることが理論的に証明され，かつ線型理論に特ける厳滵解が得られた。さらに規則的 正面向い波の場合の近似式が求められ，この式による諳算値と実験値との間にかなりよい一致が得られることが 示された。ただこの比較が一つの船型で波長が船の長さに等しい場合のみについてしか行なわれていないので, 船型や波長が変つた場合どのような結果が得られるかは明らかにされていない。

本研究では上下摇, 縦摇に対する strip method による計算值の適用性を確かめるため, なるべく計算上の不 確実な要素を少なくする目的と, 波浪中抵抗增加の計算の複雑さを避ける目的で, 丸尾が抵抗增加の計算打よび 実験に用いた数学船型を原型に選び，これと水線面形状抽よび断面形状をそれぞれ変化させた 2 寒, 計 3 隻の船 型について，波長を変えた場合の船体運動㔚よび抵抗增加の計算を行なつた。船体僬䨋では上下摇と縦摇の連成 計算と非連成計算を行なつて連成項の影響を調べ，抵抗增加の計算では丸尾の近似式に考祭を加え，若干の改良 を試みて両者の比較を行なつた。また同時にこれらの模型について実験を行ない敖算值と比較検封した。特に船 の速度の影響を広範囲に調べるためフルード数 0.5 の高速をで実施した。

\section{2 船型}

船型として次の 3 種の前後対称な数学船型を選んだ。

Model A : $\eta=\left(1-\xi^{2}\right) \cdot\left(1-\zeta^{4}\right)$

原稿受付 昭和 40 年 7 月 10 日

* 大阪大学工学部

** 防衛庁第一研究所 
Model B : $\eta=\left(1-\xi^{2}\right) \cdot\left(1-\zeta^{24}\right)$

Model $C: \eta=\left(1-\xi^{4}\right) \cdot\left(1-\zeta^{4}\right)$

ただし原点は船体中央, 水線面中心線の位置にあり, これより船首の方向に $x$ 軸を, 幅方向に $y$ 軸を, 鉛直上方 に $z$ 軸をとる。船の長さを $L$, 幅を $B$, 契水を $T$ とし, 船体表示を無次元化して $\xi=2 x / L, \eta=2 y / B, \quad \zeta=-z / T$ とする。寸法此は 3 隻とも $L / B=8, B / T=2, L / T=16$ とする。 3 種の船型のうち Model A は丸尾の波浪中抵 抗增加汇関する論文 ${ }^{1)}$ に扎いて，一部の計算および実験が行なわれた船型で，今回の計算および実験と比較する ため原型として選んだ。Model C は Model A と断面形状は同じで水線面形状を full とし,従つて方形係数の大 きな船型である。 Model B は Model A と水線面形状は同じでかつ Model C と方形係数が同じになるように 断面形状をU型にした船型である。船体をほの函数とらの函数の積の形で表わしたのは数値計算を容易にするた めである。水線面上り上部は水線面と同一形状にした。各々の正面線図をFig. 1 亿, 主要目をTable 1 亿示す。
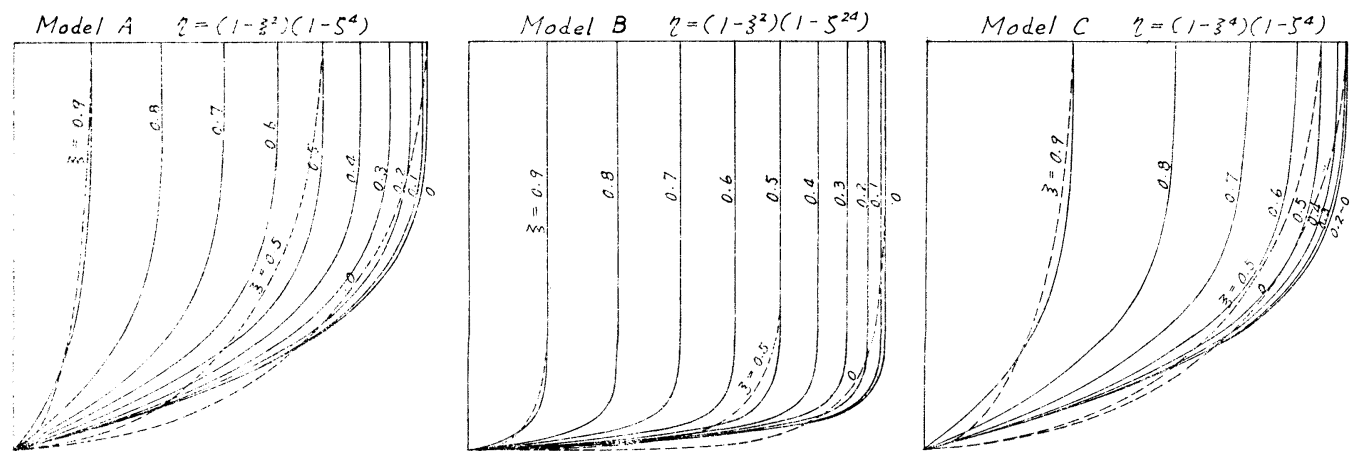

Fig. 1 Body plans.

Table 1 Principal particulars of models.

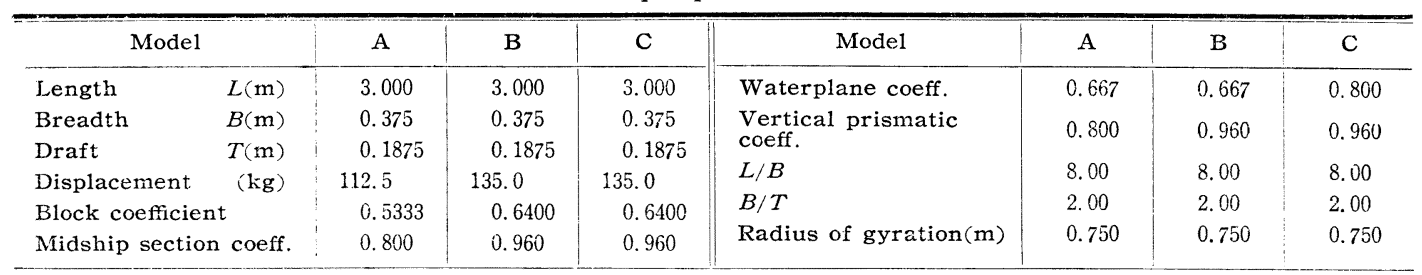

\section{3 規則波中の船体運動の計算}

涀則的证面向い波中を一定速度で直進している船の上下摇および綐摇はサージングを無視し，渡辺 ${ }^{2)}$, 福田 ${ }^{3)}$ の竍筫法汇從い strip method で求めた。上下摇 $\boldsymbol{z}$ は船体が浮き上がる方向を正に, 縦摇角 $\theta$ は船洋が持ら上が る方向を正汇とると，遇動方程式は

$$
\left.\begin{array}{l}
a \ddot{z}+b \dot{z}+c z+d \ddot{\theta}+e \dot{\hat{\theta}}+g \theta=F_{1} \cos \omega_{E} t-F_{2} \sin \omega_{E} t \\
A \ddot{\theta}+B \dot{\theta}+C \theta+D \ddot{z}+E \dot{z}+G z=M_{1} \cos \omega_{E} t-M_{2} \sin \omega_{E} t
\end{array}\right\}
$$

(1)侙の解は

$$
z=z_{0} \cos \left(\omega_{E} t+\gamma\right), \quad \theta=\theta_{0} \cos \left(\omega_{E} t+\hat{o}\right)
$$

ただし

$$
\begin{gathered}
z_{0}=\sqrt{\frac{P^{2}+Q^{2}}{R^{2}+S^{2}}, \quad \tan \gamma=\frac{R Q-S P}{R P+S Q}} \\
\theta_{0}=\sqrt{\begin{array}{c}
P^{\prime 2}+Q^{\prime 2} \\
R^{2}+S^{2}
\end{array}, \quad \tan \delta=\frac{R Q^{\prime}-S P^{\prime}}{R P^{\prime}+S Q^{\prime}}} \\
P=\left(\omega_{E}^{2} A-C\right) F_{1}+\omega_{E} \cdot B \cdot F_{2}-\left(\omega_{E}^{2} d-g\right) M_{1}-\omega_{E} \cdot e \cdot M_{2} \\
Q=\left(\omega_{T}^{2} A-C\right) F_{2}-\omega_{E} \cdot B \cdot F_{1}-\left(\omega_{E}^{2} d-g\right) M_{2}+\omega_{E} \cdot e \cdot M_{1}
\end{gathered}
$$




$$
\begin{aligned}
& P^{\prime}=\left(\omega_{E}^{2} a-c\right) M_{1}+\omega_{E} \cdot b \cdot M_{2}-\left(\omega_{E}^{2} D-G\right) F_{1}-\omega_{E} \cdot E \cdot F_{2} \\
& Q^{\prime}=\left(\omega_{E}^{2} a-c\right) M_{2}-\omega_{E} \cdot b \cdot M_{1}-\left(\omega_{E}^{2} D-G\right) F_{2}+\omega_{E} \cdot E \cdot F_{1} \\
& R=-\left(\omega_{E}^{2} a-c\right)\left(\omega_{E}^{2} A-C\right)+\left(\omega_{E}^{2} d-g\right)\left(\omega_{E}^{2} D-G\right)+\omega_{E}^{2} \cdot b \cdot B-\omega_{E}^{2} \cdot e \cdot E \\
& S=\omega_{E} b\left(\omega_{E}^{2} A-C\right)+\omega_{E} B\left(\omega_{e}^{2} a-c\right)-\omega_{E} e\left(\omega_{E}^{2} D-G\right)-\omega_{E} E\left(\omega_{E}^{2} d-g\right)
\end{aligned}
$$

今回選んだ船型はいずれす前後対称で船首船尾の断面積が 0 であるから運動方程式の各係数はかなり簡単化さ れて次のようになる。

$$
\begin{aligned}
& a=M+\Delta M, \quad \Delta M=\frac{\rho \pi}{2} \int\left\{\frac{B(x)}{2}\right\}^{2}\left(C_{0} K_{4}\right) d x \\
& b=\int N d x, \quad N=\frac{\rho g_{0}^{2}}{\left|\omega_{E}\right|^{3}} \cdot \bar{A}^{2} \\
& c=\rho g_{0} A_{w}, \quad d=0, \quad e=-V \cdot \Delta M, \quad g=-V \cdot b \\
& A=I+\Delta I, \quad \Delta I=\frac{\rho \pi}{2} \int\left\{\frac{B(x)}{2}\right\}^{2}\left(C_{0} K_{4}\right) x^{2} d x \\
& B=\int N x^{2} d x \\
& C=\rho g_{0} \int B(x) x^{2} d x-V \cdot E, \quad D=0, \quad E=V \cdot \Delta M, \quad G=0 \\
& F_{1}=\rho h e^{-k r T}\left\{g_{0} \int B(x) \cos k x d x-\omega(\omega+k V) \int S \cos k x d x\right\} \\
& F_{2}=h \omega e^{-k \gamma T} \int N \cos k x d x \\
& M_{1}=-h \omega e^{-k \gamma T} \int N x \sin k x d x \\
& M_{2}=\rho h e^{-k \gamma T}\left\{g_{0} \int B(x) \sin k x d x+\omega V \int S \cos k x d x-\omega(\omega+k V) \int S x \sin k x d x\right\}
\end{aligned}
$$

ただし $M$ : 船体質量, $\Delta M$ : 船体付加質量, $I$ : 船体質量慣性モーメント, $\Delta I$ : 船体付加質量慣性モーメント, $\rho$ : 水の密度, $g_{0}$ : 重力加速度, $V$ : 船速, $\omega$ : 波の円周波数, $\omega_{E}$ : 出会円周波数, $h:$ 波振幅, $k:$ 波数 $=2 \pi / \lambda$ ( $\lambda$ : 波長), $B(x)$ : 水線面幅, $T$ : 妿水, $\gamma$ : 横断面積係数, $\rho S$ : 各断面の付加質量, $C_{0}:$ Lewis 断面に対する付加 質量係数, $K_{4}: C_{0}$ に対する自由表面の影響係数, $N$ : 単位上下摇速度に対する減衰力, $\bar{A}$ : 減衰力係数で, 上下 摇により発散される波振幅と上下摇振幅との比で表わされる， $A_{w}$ : 水線面積；積分は船体全長について行なう。

Table 2 Natural periods of models.

\begin{tabular}{c|l|c|c|c}
\hline \multicolumn{2}{|c|}{ Mode1 } & A & B & C \\
\hline \multirow{2}{*}{ Heaving $T_{z}(\mathrm{sec})$} & Calculated & 0.949 & 1.072 & 0.970 \\
& Measured & 0.930 & 1.075 & 0.951 \\
\hline \multirow{2}{*}{ Pitching $T_{\theta}(\mathrm{sec})$} & Calculated & 0.980 & 1.103 & 0.948 \\
& Measured & 0.968 & 1.110 & 0.945 \\
\hline
\end{tabular}

計算は 3 隻とも $\lambda / L=0.5,0.75,1.0,1.25,1.5,2.0$ の 6 種についてフルード数 $F_{n}=0,0.1 ， 0.15,0.2$, $0.25,0.3,0.35,0.4,0.5$ の 9 種, 合計 54 状態について電子計算機を用いて行なつた。 $C_{0} K_{4}, \bar{A}$ の值は田才 の值 ${ }^{4}{ }^{2}$,5) 使用した。これらの值より速度 0 の固有周期 $T_{Z}, T_{\theta}$ を求め, $T_{E}$ を出会周期として同調係数 $A_{Z}, \Lambda_{\theta}$ を求めた。計算による固有周期を Table 2 に示す。計算結果は動摇振幅は無次元化し, 上下摇に対して $\zeta_{0}=z_{0} / h$,

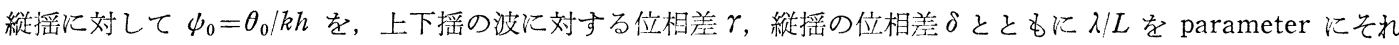
ぞれの同調係数に対して Fig. 2 に示す。また（1）式による連成計算のほかに連成項を０とした非連成計算も同 時に行なない, その結果をFig. 2 中に破線で示した。な特図には実験結果と比較するため $\lambda / L=0.75,1.0,1.5$ のものだけを示してある。また波長と動摇振幅との関係をみるため， $F_{n}$ を parameter にして連成計算による $\zeta_{0}, \psi_{0}$ を/ $/ L$ に対して Fig. 3 亿示した。これより次のことがわかる。

1) 振幅は同調係数 1 付近で最も高く，一般に波長が長い注ど振幅のピークは高い。

2) 同一波長での振幅のピークは概ね Model B, A,C の順に高い。 

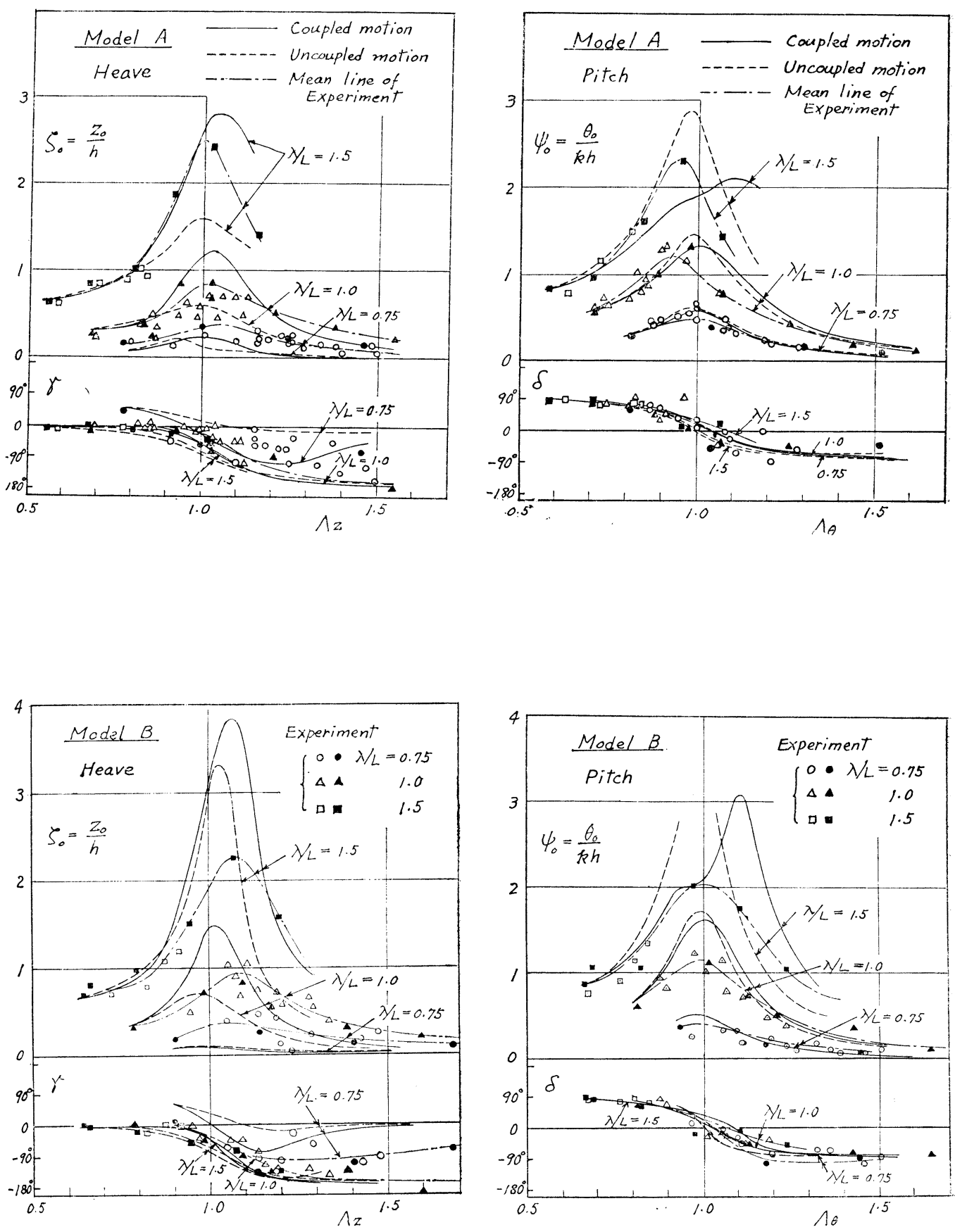

Fig. 2 Motion amplitudes and phases as a function of tuning factor. 

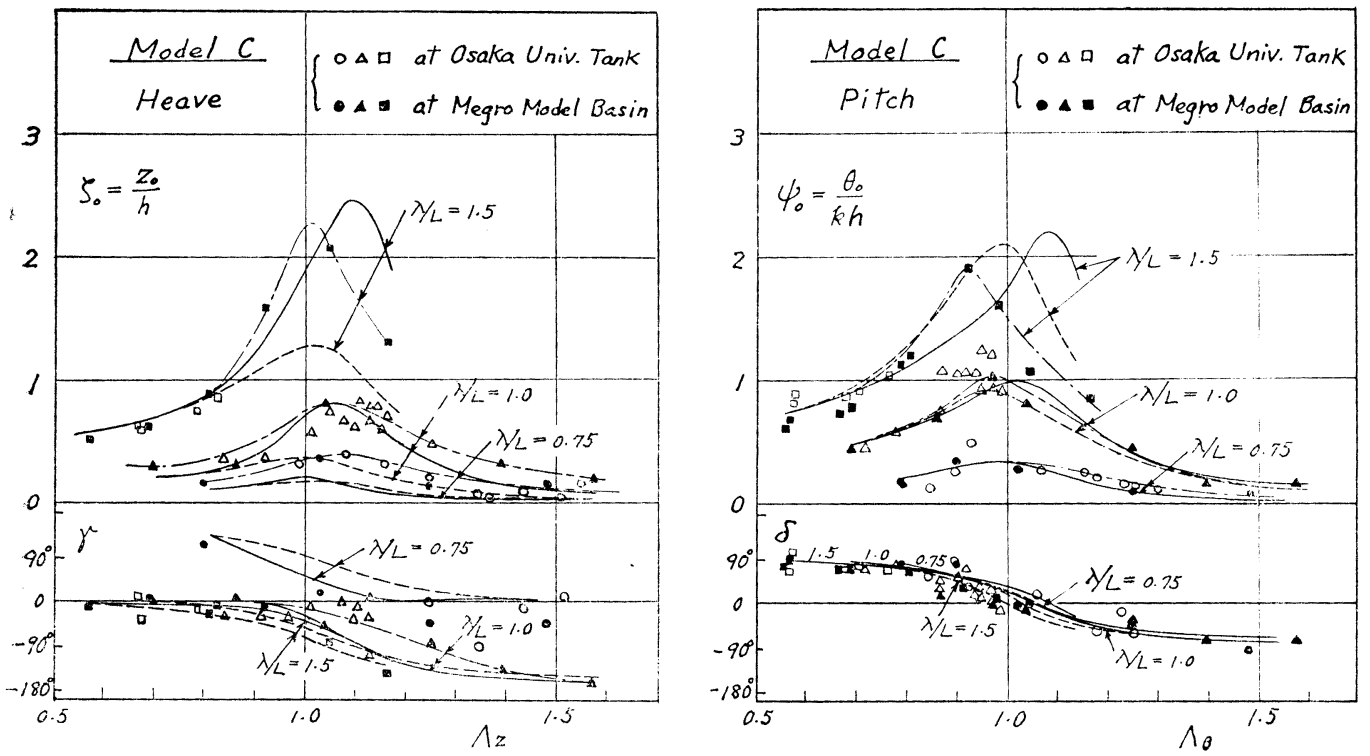

Fig. 2 Motion amplitudes and phases as a function of tuning factor.
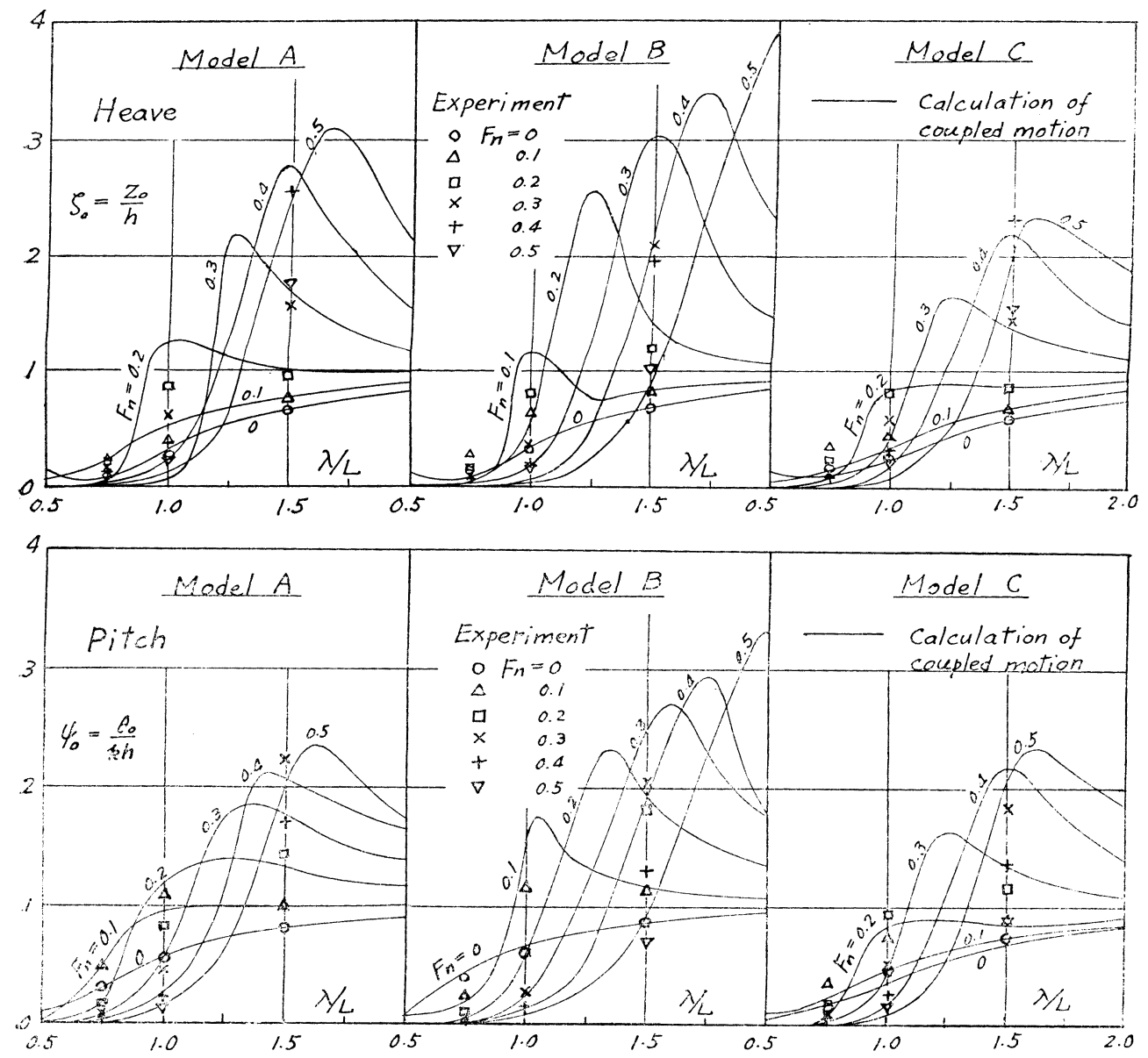

Fig. 3 Heaving and pitching amplitudes as a function of wave length. 
3）遑成計算と非連成計算とを比較すると, 縦摇では概して非連成計算の方がピークでの振幅が高く, 逆に上 下摇では非連成計算の方が低く，特に波長の長い場合にこの傾向が渚しい。また速成計算による縦摇振幅の曲緑 は波長の長い場合にこぶ状を呈することがあり，その場合にはピークの位置が非連成計算よりも同調係数の高い 方へずれる。

4) 位相差は同調係数べースに表わすと, 波長の長い場合にはほとんど一水の線にまるまるが，波長の短い晈 合, 特に上下摇では異なつた值となり，この場合には連成計算と非連成計算との差が著しい。

\section{4 規則波中の抵抗增加の計算}

正面規則波に向つて進む前後対称の船の抵抗増加 $\Delta R$ の無次元係数 $K_{w}$ は丸尾の近似式)によつて次式で与兄 られる。

$$
K_{w}=\frac{\Delta R}{\rho g_{0} h^{2} B^{2} / L}=D_{11} \zeta_{0}^{2}+D_{22} \psi_{0}^{2}+D_{33}+D_{1 \varepsilon} \zeta_{0} \psi_{0} \cos \left(\varepsilon_{1}-\varepsilon_{2}\right)+D_{13} \zeta_{0} \cos \varepsilon_{1}+D_{23} \psi_{0} \cos \varepsilon_{2}
$$

ここで各 $D$ 係数は文献 (1) の式を变形すれば次のよ5に与えられる。

$$
\begin{aligned}
D_{11}= & \frac{F_{n}^{2}}{\pi} \int\left(x+\omega_{1}\right)^{2} \cdot S(x) I^{2}(x) \exp \left[-8 \gamma(T / L) F_{n}^{2}\left(x+\omega_{1}\right)^{2}\right] d x \\
D_{22}= & \frac{\pi F_{n}^{2}}{(\lambda / L)^{2}} \int\left(x+\omega_{1}\right)^{2} S(x) \cdot J^{2}(x) \exp \left[-8 \gamma(T / L) F_{n}^{2}\left(x+\omega_{1}\right)^{2}\right] d x \\
D_{33}= & \frac{1}{2 \lambda / L} \int S(x) \cdot I^{2}\left(x+\frac{\pi}{\lambda / L}\right) \cdot\left[\exp \left\{-4 \gamma(T / L) \cdot\left[F_{n}^{2}\left(x+\omega_{1}\right)^{2}+\frac{\pi}{2 \lambda / L}\right]\right\}+2 \gamma(T / L)\right. \\
& \left.\times\left(x+\frac{\pi}{\lambda / L}\right) \exp \left\{-4 F_{n}^{2}(f / L)\left(\frac{\pi}{2 F_{n}^{2} \lambda / L}+x+\omega_{1}^{2}\right)\right\}\right]^{2} d x \\
D_{12}= & -\frac{2 F_{n}^{2}}{\lambda / L} \int\left(x+\omega_{1}\right)^{2} \cdot S(x) \cdot I(x) J(x) \exp \left[-8 \gamma(T / L)\left(x+\omega_{1}\right)^{2}\right] d x \\
D_{13}= & -F_{n} \sqrt{\frac{2}{\pi \lambda / L}} \int\left(x+\omega_{1}\right) \cdot S(x) I(x) I\left(x+\frac{\pi}{\lambda / L}\right) \cdot P(x) d x \\
D_{23}= & \frac{2 \pi}{\lambda / L} \sqrt{\frac{\pi}{\lambda / L}} \int\left(x+\omega_{1}\right) S(x) J(x) I\left(x+\frac{\pi}{\lambda / L}\right) P(x) d x
\end{aligned}
$$

ただし

$$
\begin{aligned}
& S(x)=\frac{\left(x+\frac{\pi}{\lambda / L}\right)\left(x+\omega_{1}\right)^{2}}{\sqrt{\left(x+\omega_{1}\right)^{4}-\frac{x^{2}}{4 F_{n}{ }^{2}}}} \\
& P(x)=\exp \left[-8 \gamma(T / L) F_{n}^{2}\left\{\frac{\pi}{4 F_{n}^{2} \lambda / L}+\left(x+\omega_{1}\right)^{2}\right\}\right]-2 \gamma(T / L)\left(x+\frac{\pi}{\lambda / L}\right) \\
& \quad \times \exp \left[-\frac{2 \pi}{\lambda / L} \cdot(f / L)-4 F_{n}^{2}\{\gamma(T / L)+(f / L)\} \cdot\left(x+\omega_{1}\right)^{2}\right] \\
& I(x)=\int_{0}^{1} \eta_{0}(\xi) \cos (x \cdot \xi) d \xi \\
& J(x)=\int_{0}^{1} \eta_{0}(\xi) \xi \sin (x \cdot \xi) d \xi \\
& \omega_{1}=\frac{\pi}{\lambda / L}+\frac{1}{F_{n}} \sqrt{\frac{\pi}{2 \lambda / L}} \\
& \int=-\int_{-\infty}^{-K^{\prime}}+\int_{-1 / 2 F_{n}^{2}}^{\infty} \\
& K^{\prime}=\frac{\pi}{\lambda / L}+\frac{1}{2 F_{n}^{2}}+\frac{1}{F_{n}} \sqrt{\frac{2 \pi}{\lambda / L}}
\end{aligned}
$$




$$
\begin{aligned}
& \left(-K^{\prime} \text { は } S(x)\right. \text { の分母の根号内の式の最小根) } \\
& f=\text { 水線面より浮心までの距離 } \\
& \varepsilon_{1}=-\gamma \\
& \varepsilon_{2}=\frac{\pi}{2}-\delta
\end{aligned}
$$

さて今回船体運動を strip method によつて求めたのと同様に，船体の任意の一断面に抢ける船体運動沉基つ く鉛直方向の流速を求めると, $\cos \theta \div 1$ として

$$
v_{z}=\dot{z}+x \dot{\theta}-V \theta
$$

この他に波による上下方向流速 $v_{w}$ がある。これは近似的に

$$
v_{w}=-k c h e^{-k \gamma T} \cos \left(k x+\omega_{E} t\right)
$$

々打注る。従つて船体の水注対する流速 $v_{s}$ は

$$
v_{s}=v_{z}-v_{w}
$$

ここで $\eta_{0}$ を水線面表示式として Michell 式の近似で船体を表わす吹出し分布を

$$
\sigma=-\frac{v_{s}}{2 \pi} \eta_{0}
$$

と拈く。以下交献 (6) 飞従つて計算を行ない前後対称の条件を入れると次式が得られる。

$$
\begin{aligned}
K_{w}= & D_{11} \zeta_{0}^{2}+\left(D_{220}+D_{221}+D_{222}\right) \psi_{0}^{2}+D_{33}+\left(D_{120}+D_{121}\right) \zeta_{0} \psi_{0} \cos \left(\varepsilon_{1}-\varepsilon_{2}\right)+D_{13} \zeta_{0} \cos \varepsilon_{1} \\
& +\left(D_{230}+D_{231}\right) \psi_{0} \cos \varepsilon_{2}
\end{aligned}
$$

この式は $D_{221}, D_{222}, D_{121}, D_{231}$ を 0 とすると丸尾の浮心位置の影響を考虑しない近似計算式6)と一致する。こ こに出て来た $4 つ の D$ 係数は迎克角の影響を示す項で（5）式右辺第 3 項より得られ，次式で表わせる。

$$
\left.\begin{array}{l}
D_{221}=\frac{2 \pi F_{n}^{2}}{(\lambda / L)^{2}} \int\left(x+\omega_{1}\right) S(x) I(x) J(x) \exp \left\{-8 \gamma(T / L) F_{n}^{2}\left(x+\omega_{1}\right)^{2}\right\} d x \\
D_{222}=\frac{\pi F_{n}^{2}}{(\lambda / L)^{2}} \int S(x) I^{2}(x) \exp \left\{-8 \gamma(T / L) F_{n}{ }^{2}\left(x+\omega_{1}\right)^{2}\right\} d x \\
D_{121}=-\frac{2 F_{n}^{2}}{\lambda / L} \int\left(x+\omega_{1}\right) S(x) I^{2}(x) \exp \left\{-8 \gamma(T / L) F_{n}^{2}\left(x+\omega_{1}\right)^{2}\right\} d x \\
D_{231}=\frac{F_{n}}{\lambda / L} \sqrt{\frac{2 \pi}{\lambda / L}} \int S(x) I(x) I\left(x+\frac{\pi}{\lambda / L}\right) \exp \left[-8 \gamma(T / L) F_{n}^{2}\left(x+\omega_{1}\right)^{2}-\frac{2 \pi}{\lambda / L} \gamma(T / L)\right] d x
\end{array}\right\}
$$

これらは (4) 式の $D_{i j}$ の被積分函数をそれぞれ $d_{i j}$ で表わすと近似的に次式で求まる。

$$
\left.\begin{array}{rl}
D_{221} & =-\frac{\pi}{\lambda / L} \int \frac{d_{12}}{\left(x+\omega_{1}\right)} d x \\
D_{222} & =\left(\frac{\pi}{\lambda / L}\right)^{2} \int \frac{d_{11}}{\left(x+\omega_{1}\right)^{2}} d x \\
D_{121} & =-\frac{2 \pi}{\lambda / L} \int \frac{d_{11}}{\left(x+\omega_{1}\right)} d x \\
D_{231} & =-\frac{\pi}{\lambda / L} \int \frac{d_{13}}{\left(x+\omega_{1}\right)} d x
\end{array}\right\}
$$

今回は計算の都合上 $(4)$ 式扣よび (11) 式によつて $K_{w}$ を求めた。上記 $D$ 係数の計算は電子計算機扣よび筆 算により，積分はSimpson 第一法則およびプラニメーターによつた。計算した状態は $\lambda / L=0.75,1.0,1.5$ の 3 種について $F_{n}=0.1 ， 0.2 ， 0.3 ， 0.4 ， 0.5$ の 5 種, 合計 15 状態である。計算結果を $F_{n}$ ベースで Fig. 4 に示す。 このうち Model A の $\lambda / L=1.0, F_{n}=0.1 \sim 0.3$ Kついては上にあげた丸尾の計算值があるが, 今回計算した值 はこれらとほぼ一致する。

Fig. 4 上り次のことがわかる。

1) $D$ 係数は一般に速度增大に伴つて絶対值が減少する傾向を示す。

2) 各 $D$ 係数の 万ち縦摇振幅に関係する係数 $\left(D_{220}\right)$ は一般に優勢であるが，長い波長，高速時には上下摇振 幅に関係する $D_{11}$ が優勢となる。

3）低速では波長増大に伴つて $D$ 係数は減少する傾向を示すが，高速では增大の傾向を持つるのもある。

4) 一般に Model C, A, B の順に数值が大きい。これは運勒振幅の計算値とは逆の傾向である。 


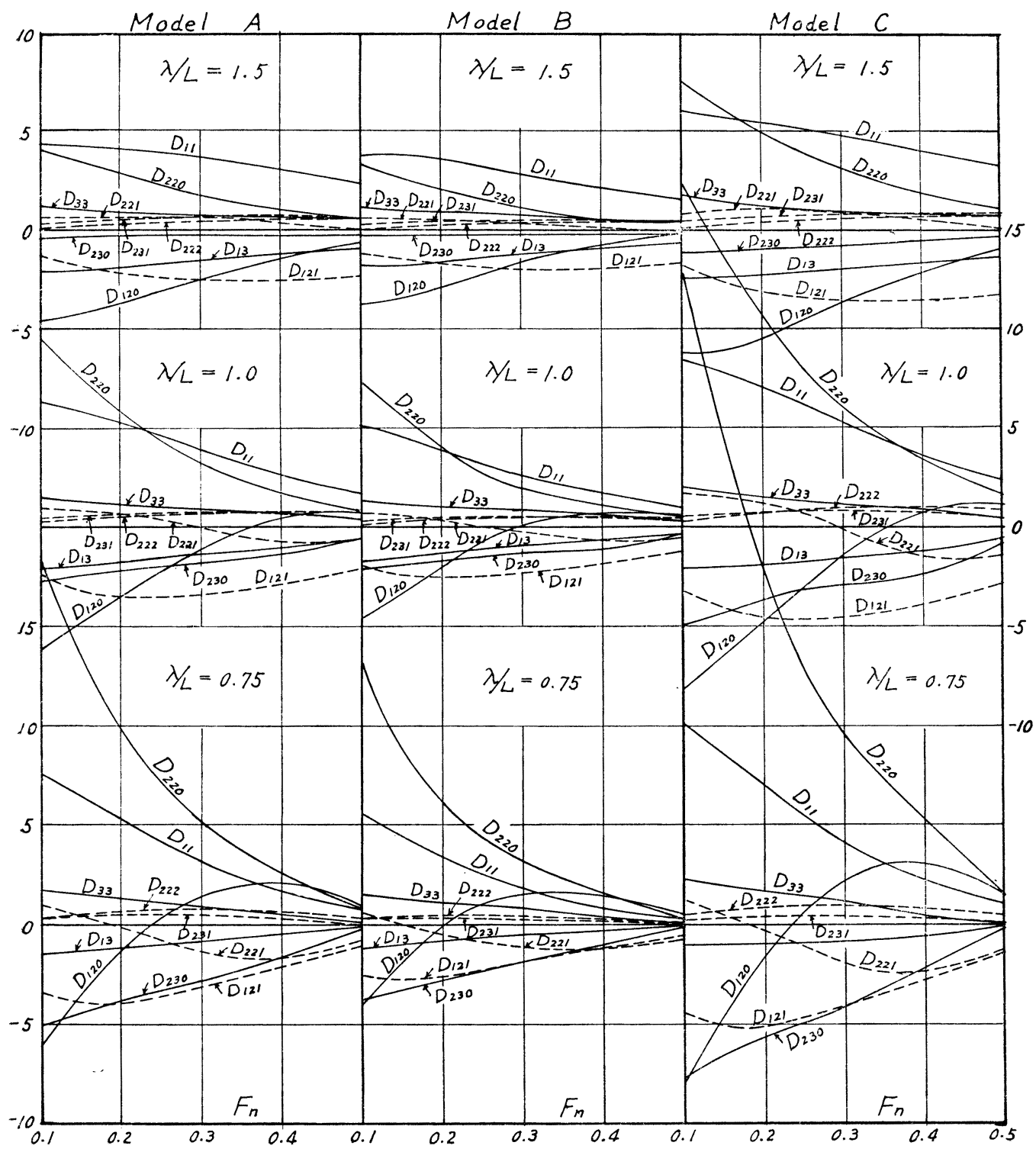

Fig. 4 Coefficients of components of resistance increase.

5）迎兄角の影響を示す係数は一般に值が小さいが，縦摇と上下摇との位相差に関する係数 $D_{121}$ のみは大き く，特渂速時，波長の長いときに著しい。

\section{5 実}

験

実験は長さ $3 \mathrm{~m}$ の木製模型船について行なつた。いずれる船首より $5 \% \mathrm{~L}$ の位置に乱流促進のために幅約 $2 \mathrm{~mm}$ のスタッドを $10 \mathrm{~mm}$ 間隔で, 高さ $1.6 \mathrm{~mm}$ に植えた。慣性半径は空気中で $L / 4$ 亿合わせ, 固有周期は静水中で 縱摇, 上下摇の夕の自由動摇を行なわせて測定しさ。測定した固有周期は Table 2 に示してある。平水中抵抗試

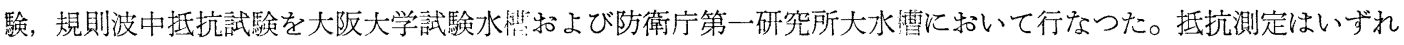
も重鍾式により, 定引車と模型船との間の相対速度は前者はプーリーの動きをペン書きし, 後者では運動測定金 具の移動をポテンショメーターを使用して電気的に測定し, 上下摇, 縦摇の計測はいずれるポテンショメーター を使用した測定金具により，波高は前者では金属板型波高計に，後者では超音波波高計によつて測定した。 
波長は計算値との比較上 $\lambda / L=0.75,1.0,1.5$ の 3 種に重点をおき阪大水灀では $\lambda / L=0.5 \sim 2.0$ で速度は $F_{n}=0.3$ までを行ない, 防衛庁水糟では上記 3 種の波長で速度範囲は $F_{n}=0.5$ まで実験した。波高は $5 \mathrm{~cm} \sim$ $3.5 \mathrm{~cm}$ とし, 甲板に被水する状態はできるだけ避けた。な拈一部の波長, 速度については波高を $3 \mathrm{~cm}$ より $9 \mathrm{~cm}$ まで変化させて実験し, 振幅, 抵抗增加の無次元值が変らないことを確かめた。実験值は上下摇, 縱摇の振幅招 よび位相差を Fig. 2 中に, 抵抗增加係数を Fig. 5 に示す。また上下摇, 縦摇振幅の実験值の平均維より求的た 各フルード数每の值を Fig. 3 中に記入した。

\section{6 計算と実験の比較}

上下摇，縦摇の連成計算による計算値と実験值を比皎すれば Fig. 2, Fig. 3 より次のことがい党る。

1) 振幅, 位相差ともに全体の傾向は計算と実験とで同一であるが, 数量的にはかなりの差のある場合もある。

2) 速度 0 の固有周期, 動摇振幅はかなり良い一致を示した。

8) 上下摇振幅は Model A，B はピークで実験值は計算值より低いが，Model C は概して同じである。波長 の短いときは一般に実験值が高く，波長の長いときは低速では割合よく合つているが高速ではかなり差がある。

4) 綐摇振幅は各船型とも波長が短いときはよく合つている。波長が長い場合, ピークの高さは Model A, C は概补合つているが, Model B ではかなり実験值が低い。

5）位相差は縱摇については実験值は全体として割合よい一致を示しているが，上下摇については縦摇に比べ るとやや差がある。

つぎに上下摇, 縦摇の非連成計算值と比較すると波長の長い場合振幅にピークの現われる同調係数の值はむし ろ非連成計算值の方が実歌值に近い。連成計算の方が非連成計算よりも実験值によく合らという結諭は今回の荚 験からは確認できなかつた。

速度 0 の場合連成項は０となり連成計算と非連成計算とは一致するが，このときは計算値と実験值とがかなり よく一致していることから, 連成項の計算法に問題があるょ５に思われる。しかも速度が増大するに従つて影響 の大きくなる項はいずれる付加質量拉よび減衰力に関係する項であるから, 結局 $C_{0} K_{4}, \bar{A}$ の推定の誤差に起因 る問題であろう。今回選んだ船型は各断面が簡単な多項式で表現できるすので, Lewis 断面ではない。比較のた め代表的断面について今回の模型と同じ断面積係数抢よび幅契水比に相当する Lewis 断面を示すと Fig. 1 の破 線のようになる。田才の $C_{0} K_{4}, \bar{A}$ は Lewis 断面に対する值でその值をそのまま使用したことに誤差の一因があ るよ弓にも思われる。

減衰力に対する 3 次元影響係数を求めた Havelock ${ }^{7)}$, Vossers $^{8)}$, Kaplan ${ }^{9}$ の計算および Gerritsma, Golovato の実験值より推定した田才゙ ${ }^{5}$ の值によれば周波数によつて变化するが，今回の実験に相当する周波数では最大約 1.4 になつている。これらより strip method によつて求めた減衰力は低目の值を与兄ることが多いことがわか り，ピークの振幅について計算值は実験值と同じ程度かあるいは高いということを説明するものであろう。速度 0 亿打ける固有周期は計算値と実験值とよく一致しているからこれは付加質量の推定に大きな䛊りがなかつたこ とを示している。上記の減衰力に関する 3 次元影響俰数の資料によれば速度增加に伴つて值は 1 に近づき，また 速度 0 の時の付加質量推定に誤差が少ないことから, 振幅について計算值と実験值との著しい差は, 付加質量お よび減衰力に対する速度の影響や, 速度増加に基つくく船体沈下量, トリム角, 定常造波等の影響によるものと考 爷らる。

波の強制力は平均哭水 $r T$ に働くものとして計算を行なつたがこれは厳密ではなく，特に短い波長のときに誤 差が大きくなる。しかしこれは振幅にはあまり大きな影響を与えない。従つて波長が短いときには計算された強 制力は小さい值を与えるが，実際はもつと大きな值であることが予想される。

抵抗增加の計算は Fig. 4 の D係数と Fig. 2 中に示す動摇振幅および位相差の実験值の平均線の值を用いて求 めた。抵抗增加係数の各成分ごとの值を Fig. 5 に示し，全体の抵抗增加係数をFig. 6 亿示す。Fig. 5, 6 中の 実線は丸尾の式 (3) によるもので, 今回迎え角の影響を考虑した計算式 (9) によるものを点線で示した。これ らの図より次の結果が得られた。

1) 抵抗增加係数 $K_{w}$ の傾向は計算值と実験值は一致する。

2) $\lambda / L=0.75,1.0$ については低速部を除き扮扮むね一致する。

3) $\lambda / L=1.5$ では Mode1 A，B は実験值が高いが，Mode1 C は低い。 


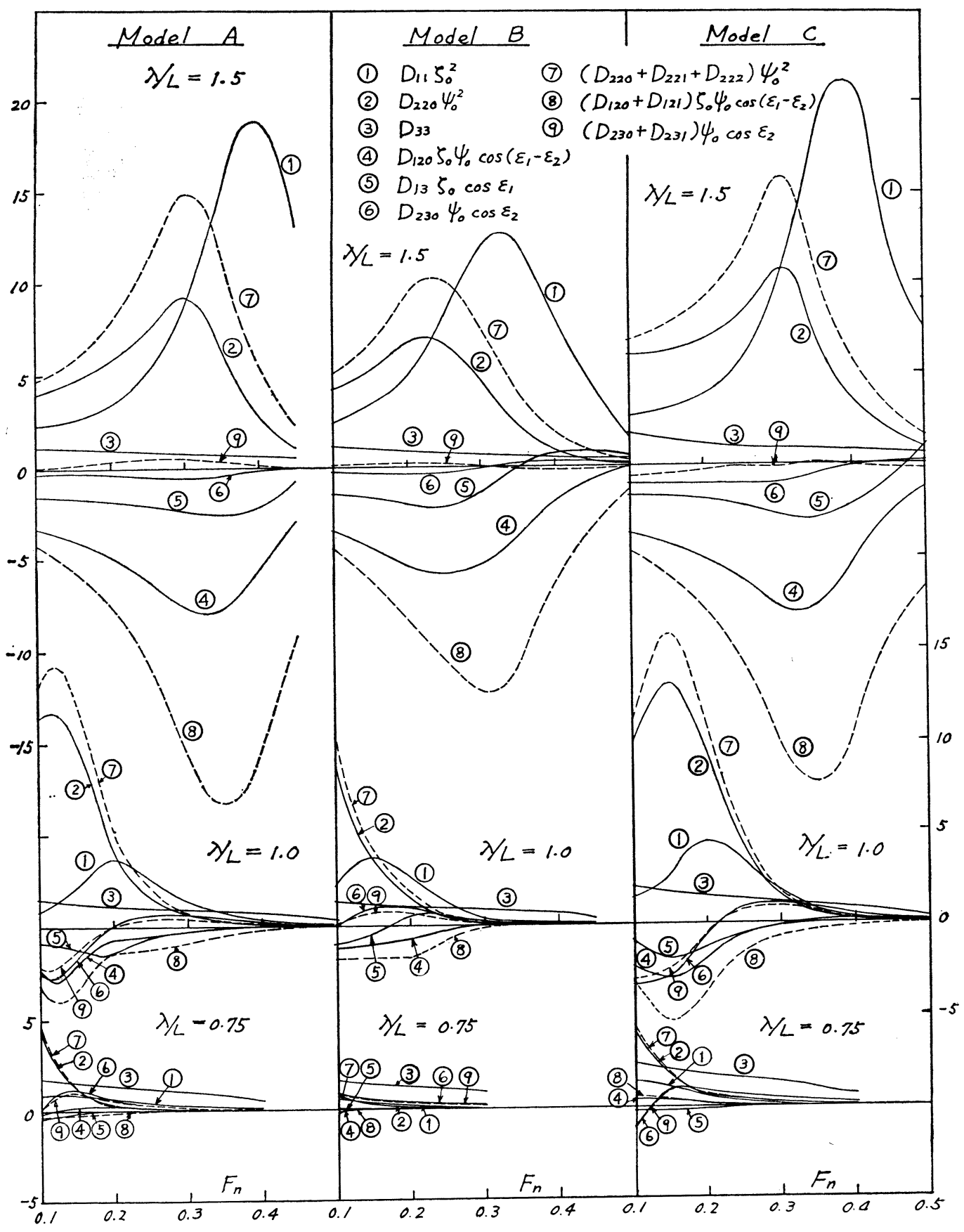

Fig. 5 Components of resistance increase coefficients. 
4) $K_{w}$ は運動振幅の最も大きい同調係数 1 付近で最大となる。同調係数増大に伴つて抵抗 増加は次第に減少していくが，同一同調係数の ときには波長によらず抵抗増加はほぼ同一の値 を示している。

5）迎光角の影響を示す項は波長の短いとき には小さな值で，波長が長く，かつ速度が大き いとさにのみ大さい值を示す。実験值と比較す ると Model A, B はこの影響を取り入れない力 がかえつてよく合うが, Model C は影響を取り

入れた方がよい。

6) 運動に strip method による計算値を使 つた場合と実験值を使つた場合とを比較した結 果，実験値を使用した方が概してよい。

抵抗増加の成分をFig. 5 より判断すると，波 長の短い低速部では縦摇による抵抗増加が, 優 勢であるが波長の長い高速部では上下摇による ものが優勢となる。波長の短い場合で高速時に は運動振幅がほとんど 0 となり船体表面での波 の反射に基づく抵抗増加分が主要な割合を占め る。迎兄角の影響は縦摇振幅に基づく項は増大 し, 上下摇と縦摇との位相差に基づく項は逆に 減少し，この傾向は波長が長いほど著しい。

ここです船体運動と同様に種々問題点がある ように思われる。すなわち strip methodを用 いたために吹出し分布の決定に 3 次元影響を考 える必要があること, 高速時に船体沈下とトリ ムを起こすことによる影響, 波の力が平均喫水 に働くとした点の影響もあると思われる。しか しこのような影響を計算に取り入れることは計 算を極めて複雑にしてしまうので，現実的には 行ない難いよ5に思われる。迎え角の影響につ いては今回明確な結論が得られなかつたので今 後の問題として残される。しかし波長の短いと き，波長の長くて低速のときには影響が少ない

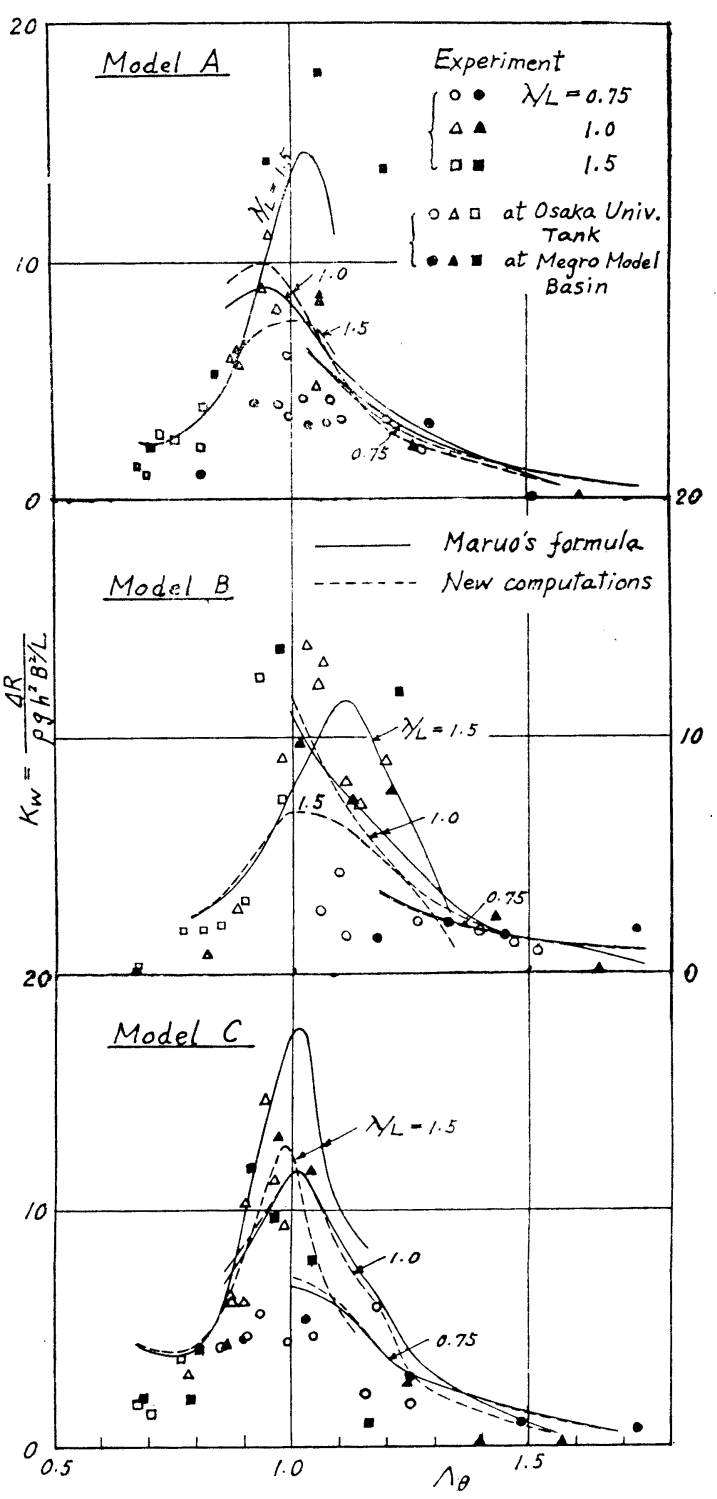

Fig. 6 Total resistance increase coefficients.

ことが判明したから，そのような目的に使用される船の場合は計算に取り入れる必要はないように思われる。た だしここにとりあげた船はいずれる前後対称の船型であるが実際の船型は前後非対称で，副部もあるから実用船 型にこの計算を適用するとかなり複雑になる。（前後非対称で副部を考えない場合 4 節で行なつた計算で $D$ 係数 の数は28ケとなり，このうち迎え角の影響項は 10 ケである。）

\section{7 船型の比較}

長さ，幅，哭水の同一な船 3 隻について運動計算，抵抗増加計算および実験を行なつたので船型の比較ができ る。まず運動振幅は先にあげたようにピークの值は Model B, A, C の順となる。これより断面形状の差が著しく 影響することが判る。Model B と C は同一排水量で, 断面の形は Model B はU型，CはV型である。これより U 型の方が振幅が大きいという結が得られる。Model A は C と断面形状が同一であるが水線形状は Model A の 方がやせている。これより水線面積係数の大きい方が振幅は小さいといえる。抵抗增加を示す $D$ 係数は Model C, 
A，B の順に大きい。これらを組み合わせた $K_{w}$ の形で比較すると扣招む称類似の值となつてしまう。 $\lambda / L=1.5$ の場合は計算では Model C, A, B の順汇大きいが, 実験值はModel B, A, C の順であつて結論は引き出せない。 $\lambda \mid L=1.0,0.75$ の場合は運動振幅と $D$ 係数との大小関倸が逆であるために, 打互いに打ち消し合つて抵抗增加は 泳同一になるのであろう。Model A と B または C とは方形係数が異なるが， $K_{w}$ の值にさした差がみられな いことは方形係数はさ活ど重要な因子ではないように思われる。固有周期は長い方から上下摇で Model B, C, A, 綐摇で Model B, A,C の順である。したがつて同一速度, 同一波長で同調係数の值が異なる。今回の計算值だけ からいえば， $\lambda / L=1.0$ での最大の $K_{w}$ の值は Model A で $F_{n}=0.15$, B で 0.1，C で 0.2 となる。したがつて 同一速度同一波長での抵抗增加の比較は複雑な椂相を示す。 Model B と C とではU 型船と V 型船の比較になる が，低速では Bが，高速ではC C゙抵抗增加が大きいから，単に船型のみによる比較は困難である。

\section{8 結}

\section{言}

簡単な数式表示による船型について規則波に向つて航走する場合の船体運動ならびに抵抗増加について近似計 算拉よび実験を行ない次の結論を得た。

1） Strip method による船体運動計算は傾向は扮招むね実験と合らが, 数值的には予想外に合わない場合が あり, 特に短波長の上下摇特よび高速時の動摇振幅に著しい。これは断面の近似の影響, 減衰力の 3 次元影響, 速度の影響, 連成項の計算法の不完全さ等と考兄られる。

2）抵抗増加の計算は長波長の高速時を除いて実験値とかなり一致する。今回取り入れた迎方角の影響は長波 長の高速時に現われるが実験値と比較していずれがよく合うかについては結論は得られなかつた。

3）船型の比較として方形係数は主要な因子として現われなかつた。U 型船と $\mathrm{V}$ 型船とを比較するとU 型船は 運動振幅は大きいが $D$ 係数は小さく, $\mathrm{V}$ 型船はその逆であり結局抵抗増加はほぼ同一であるが, 同調係数の值に よつて判断の必要がある。

終りに臨み本研究に助言をいただいた横浜国立大学丸尾教授に対し謝意を表します。また船体運動の計算には 三菱重工業の電子計算機を使用させていただき，この面で同社神戸研究所藤井斉技師のご厚意に感謝致します。 さらに計算ならびに実験を実施していただいた大阪大学船舶試験水槽特よび防衛庁水槽の職員各位のご尽力, 特 に直接数值計算挌よび実験解析にあたられた大阪大学大学院工学研究科の細田竜介, 宮本雅史両君のご労苦に衷 心より就礼申し上げます。

な打本研究は昭和 39 年度文部省科学研究費による研究の一部であることを付記する。

\section{参 考 文 献}

1）丸尾 孟：波浪中の船体抵抗增加に関する研究（第 1 報)，造船協会論文集，第 101 号 (1957) p. 33

2) 渡辺恵弘：船の上下動及び縱摇の理論流て，九大工学集報，第 31 巻，第 1 号 (1958) p. 26

3）福田淳一：規則波中の船の縦曲げモーメント，造船協会論文集，第 110 号 (1961) p. 241

4) 田才福造：船の上下動摇並びに綐動摇に於ける減衰力及び附加質量について，造船協会論文集，第 105 号 (1959) p. 47

5）田才福造：船の Heaving 並びに Pitching に対する附加質量及び減衰力（続)，西部造船会々報，第 21 号 (1961) p. 109

6) Researches on Seakeeping Qualities of Ships in Japan, 造船協会 60 周年記念叢書, Vol. 8 (1963) p. 89

7) T. H. Havelock : The Damping of Heave and Pitch : A Comparison of Two-dimensional and Threedimensional Calculations, T. I. N.A. Vol. 98 (1956) p. 464

8) G. Vossers : 7) 中の討論

9) Paul Kaplan and Pung Nien Hu : Three-Dimensional Stripwise Damping Coefficients for Heave and Pitch of a Submerged Slender Spheroid, Journal of Ship Research, Vol.4, No.1 (1960) p. 1 